\title{
Women and Science: a portrait of herpetology in the state of Piauí
}

\author{
R. A. Benício ${ }^{a *}$ and M. G. Fonseca ${ }^{b}$ \\ aPrograma de Pós-graduação em Ecologia e Recursos Naturais, Universidade Federal de São Carlos - UFSCar, \\ Rodovia Washington Luiz, Km 235, CEP 13565-905, São Carlos, SP, Brasil

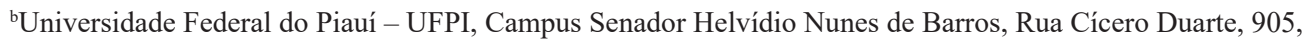 \\ CEP 64600-000, Picos, PI, Brasil \\ *e-mail: benicio.ufscar@gmail.com
}

Received: March 16, 2018 - Accepted: April 19, 2018 - Distributed: November 30, 2019

(With 1 figure)

Recently a Brazilian researcher has received great attention in national and international media by prize Rising Talents from L'Oreal's For Women in Science program 2016, which has partnered with Unesco and the Brazilian Academy of Sciences, and awards women scientists who have contributed significantly to the advancement of Science. However, locally, what does this award represent? Does it, in fact, demonstrate a greater participation of women in science? How is the participation of women scientists in Piauí? What is the representativeness of women in the publications of herpetology in Piauí?

With the objective of make a punctual portrait of this representativeness, here, we analyzed, in a very preliminary way, the representativeness of women scientists in the publications on herpetology in the state of Piauí. For this, we analyzed publications (national and international) about all the aspects of herpetology (e.g., community ecology, new species records, species lists and description of new species) carried out in the state of Piauí between 2001 and 2017, through extensive searches on the websites Web of Science (2018), Google Scholar (2018) and specialized journals. We chose the state of Piauí as an empirical universe because it is my state of origin (first author) and herpetology because it is our specialty. In addition, in this case, the state of Piauí represents an important model of study because the number of publications about the herpetology of the state has grown exponentially in the last ten years, through the publication of a considerable number of studies.

We found that there is still a very great inequality in the representation of women in science in the state of Piauí (specifically in herpetology). Although there has been a greater participation of women in the publications on the herpetology in the state of Piauí in recent years, its representativeness is much lower in relation to the number of authors men (Figure 1). For example, in the years 2001, 2005 and 2006, no woman was author or co-author of the works published in those years. In addition, during the 17 years analyzed, only in 2007 the number of women in the publications was higher than that of men (Figure 1).

To date, were published 49 articles on herpetology in the state of Piauí, in 21 national and international circulation journals (Table 1). Of these, $92 \%(n=45)$ of the articles were published by men, being that in $71 \%(n=35)$ of them

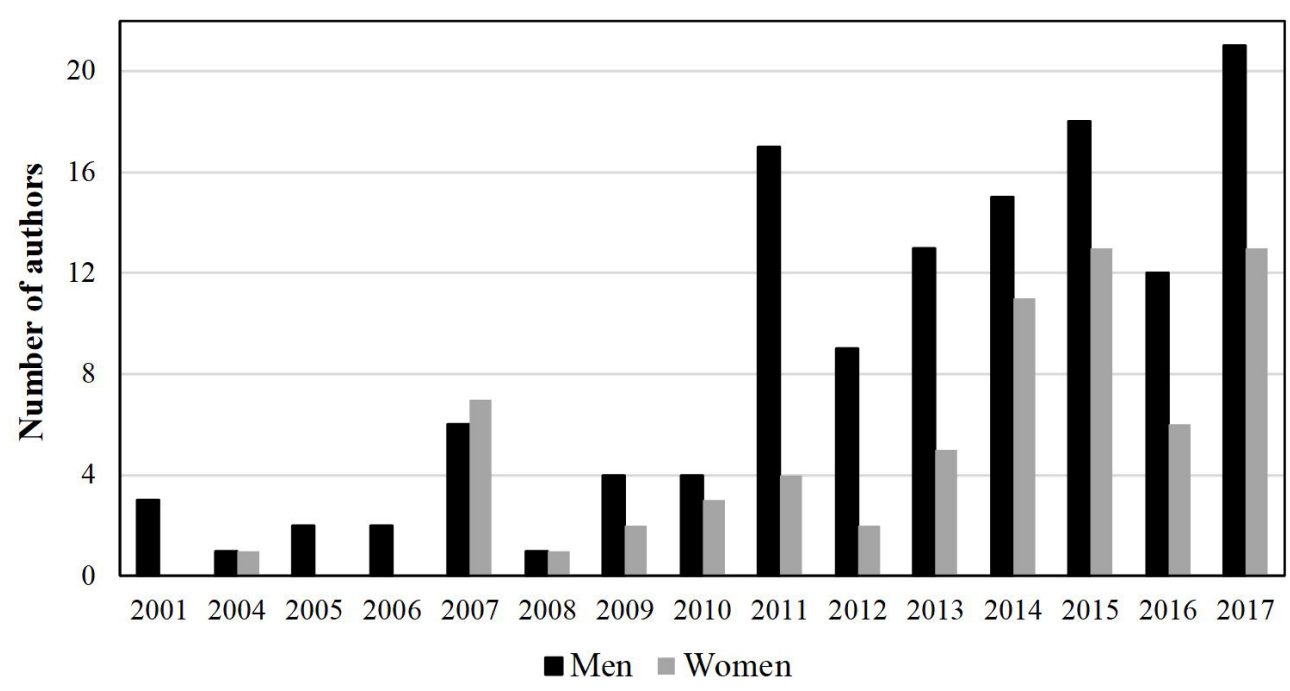

Figure 1. Distribution of the number of men and women authors in the 49 articles analyzed on herpetology in the state of Piauí between the years 2001 and 2017. There was no publication in the years 2002 and 2003. 
Table 1. Articles (ART) on herpetology in the state of Piauí, between 2001 and 2017.

\begin{tabular}{|c|c|c|c|c|}
\hline ART & Journal & N_A & N_M & N_W \\
\hline ART1* & Papéis Avulsos de Zoologia & 3 & 3 & 0 \\
\hline ART2 & Publicações Avulsas Ciências Ambientais & 2 & 1 & 1 \\
\hline ART3* & Papéis Avulsos de Zoologia & 2 & 2 & 0 \\
\hline ART4* & South American Journal of Herpetology & 2 & 2 & 0 \\
\hline ART5 & Check List & 5 & 3 & 2 \\
\hline ART6 & Herpetological Review & 4 & 1 & 3 \\
\hline ART7 & Herpetological Review & 3 & 1 & 2 \\
\hline ART8 & Check List & 2 & 1 & 1 \\
\hline ART9 & Herpetological Review & 3 & 2 & 1 \\
\hline ART10 & Herpetological Review & 3 & 2 & 1 \\
\hline ART11** & South American Journal of Herpetology & 2 & 0 & 2 \\
\hline ART12 & Herpetological Review & 5 & 4 & 1 \\
\hline ART13 & Check List & 3 & 2 & 1 \\
\hline ART14* & Zootaxa & 4 & 4 & 0 \\
\hline ART15 & Check List & 3 & 2 & 1 \\
\hline ART16* & Check List & 4 & 4 & 0 \\
\hline ART17* & Herpetology Notes & 5 & 5 & 0 \\
\hline ART18** & Zoologia & 2 & 0 & 2 \\
\hline ART19 & Check List & 3 & 2 & 1 \\
\hline ART20* & Herpetology Notes & 2 & 2 & 0 \\
\hline ART21 & Check List & 3 & 2 & 1 \\
\hline ART22* & Boletín de la Asociación Herpetológica Española & 3 & 3 & 0 \\
\hline ART23* & Papéis Avulsos de Zoologia & 4 & 4 & 0 \\
\hline ART24* & Biota Neotropica & 3 & 3 & 0 \\
\hline ART25* & Zootaxa & 3 & 3 & 0 \\
\hline ART26** & Zootaxa & 2 & 0 & 2 \\
\hline ART27 & ZooKeys & 6 & 3 & 3 \\
\hline ART28 & Cuadernos de Herpetología & 2 & 1 & 1 \\
\hline ART29 & Boletim do Museu Paraense Emílio Goeldi & 3 & 2 & 1 \\
\hline ART30 & Check List & 11 & 8 & 3 \\
\hline ART31 & International Journal of Ecology and Environmental Sciences & 5 & 2 & 3 \\
\hline ART32 & Herpetological Review & 5 & 2 & 3 \\
\hline ART33 & Gaia Scientia & 3 & 2 & 1 \\
\hline ART34 & Gaia Scientia & 4 & 3 & 1 \\
\hline ART35 & International Journal of Ecology and Environmental Sciences & 5 & 2 & 3 \\
\hline ART36 & Journal of Herpetology & 5 & 4 & 1 \\
\hline ART37 & Zootaxa & 6 & 3 & 3 \\
\hline ART38 & Boletim do Museu de Biologia Mello Leitão & 3 & 2 & 1 \\
\hline ART39 & Herpetological Review & 5 & 2 & 3 \\
\hline ART40* & Biota Neotropica & 5 & 5 & 0 \\
\hline ART41 & International Journal of Ecology and Environmental Sciences & 6 & 3 & 3 \\
\hline ART42 & Revista Nordestina de Zoologia & 4 & 2 & 2 \\
\hline ART43 & Revista Nordestina de Zoologia & 3 & 2 & 1 \\
\hline ART44 & Tropical Zoology & 6 & 3 & 3 \\
\hline ART45 & Papéis Avulsos de Zoologia & 3 & 2 & 1 \\
\hline ART46* & Brazilian Journal of Biology & 4 & 4 & 0 \\
\hline ART47 & Revista Nordestina de Zoologia & 4 & 3 & 1 \\
\hline ART48 & Austral Ecology & 10 & 7 & 3 \\
\hline ART49 & Revista Nordestina de Zoologia & 3 & 2 & 1 \\
\hline
\end{tabular}

N_A = numbers of authors; N_M = numbers of authors men; N_W = numbers of authors women; *Article composed exclusively by men; **Article composed exclusively by women. 
a man was the principal author. In $71 \%(n=35)$ of articles was composed by women, however, in only $30 \%(n=15)$ of all published articles the women were the first authors. These 15 articles were written by only seven women, one of which published 5 of them. Thus, to date, all research done with the herpetology in the state of Piauí has been concentrated in seven women.

Although there is no difference in the professional quality of these authors (e.g., most have Ph.D.), the number of men and women who composed the articles was quite uneven, in number and composition. In the 49 articles analyzed, the number of times a man's name $(n=127)$ appeared as the author was significantly greater $(p<0.001)$ than the number of times a woman's name $(n=64)$ appeared as the author or co-author. Furthermore, about $27 \%$ of the articles $(n=13)$ were composed exclusively of men, whereas only three articles had exclusively women as authors and coauthors (Table 1).

This inequality certainly does not result from a difference in the professional capacity of women, but rather of a clear inequality in the labor market insertion, hiring teachers, lower wages, fewer funded and approved projects, and inequality each professional transition stage (Carnaval, 2016). Currently, the state of Piauí does not have any Postgraduate Program (masters and $\mathrm{PhD}$ level) in the area of Zoology or Ecology (Plataforma Sucupira, 2018). This should be an important factor to consider. Although this work portrays a punctual view of the local reality and of a specific area, being necessary to know how does Piauí compare with other states, and other academic or professional areas, not only in herpetology, this study represents a formidable opportunity to collect, organize, present and discuss important data on academic representation and demonstrates the urgent need to create means and a greater incentive for the participation of women in scientific productivity in the state of Piauí.

\section{Acknowledgements}

R.A. Benício thanks Fundação de Amparo à Pesquisa do Estado de São Paulo (FAPESP, Proc. 2015/11821-0) for financial support.

\section{References}

CARNAVAL, A.C., 2016. Breve reflexão sobre mulheres cientistas, e nossa representatividade na Sociedade Brasileira de Herpetologia. Herpetologia Brasileira, vol. 5, no. 2, pp. 47-48.

GOOGLE SCHOLAR [online], 2018 [viewed 16 March 2018]. Available from: http://scholar.google.com.br

PLATAFORMA SUCUPIRA [online], 2018 [viewed 16 March 2018]. Available from: https://sucupira.capes.gov.br

WEB OF SCIENCE [online], 2018 [viewed 16 March 2018]. Available from: http://apps.isiknowledge.com 